\title{
Investigation of maximum overheating device dependence on its size and installation density
}

\author{
Semenets Valerii ${ }^{1}$ \\ Sinotin Anatoly ${ }^{2}$ \\ Sotnik Svetlana ${ }^{3}$
}

${ }^{1}$ Kharkiv National University of Radio Electronics, 14 Nauky Ave, KharkivUA-61166, Ukraine, e-mail: valery.semenets@nure.ua

${ }^{2}$ Kharkiv National University of Radio Electronics, 14 Nauky Ave, KharkivUA-61166,Ukraine, e-mail: anatolii.sinotin@nure.ua

${ }^{3}$ Kharkiv National University of Radio Electronics, 14 Nauky Ave, KharkivUA-61166,Ukraine, e-mail: svetlana.sotnik@nure.ua
Abstract. The theses show the results of influence studies of heated zone volume of an electronic device on its maximum overheating.

Keywords: heated, zone, anisotropy, thermal conductivity, conductive, heat sinks, coefficient, heat.

\section{INTRODUCTION AND PROBLEM STATEMENT}

The design of modern devices, along with the development of electrical circuits, requires strict consideration of temperature regime of future design. This poses a challenge for designer to carry out thermophysical design at all stages of development of reliable, economical, small-sized radioelectronic equipment (REE). An attempt to empirically search for an acceptable variant of constructions becomes economically unjustified.

Incorrect placement of one element can be easily detected and eliminated in process of temperature testing (verification calculations) of finished design. The elimination of errors in general layout of elements requires additional overhead for processing the entire design of apparatus. This poses before designer the task of ensuring the normal thermal regime of elements at all stages of apparatus development.

Purpose of study is establishing the nature of apparatus size influence on temperature regime of created design.

Formulation of problem. Literary sources on thermophysical design of REE with a given thermal regime are represented mainly by journal articles. The main developments are aimed at selection and optimal use of air cooling systems. Monographs on general design of REE provide only verification calculations of temperature fields.

Thermophysical design is carried out on basis of multiple calculations for various parameter values, i.e. trial and error method is used. This work presents the results of study of heated zone shape influence on maximum overheating of apparatus.

\section{PROBLEM SOLUTION AND RESULTS}

The effect of apparatus volume on maximum overheating of instrument can be expressed in terms of so-called initial parameter $\mathrm{F}_{0}$

$$
\begin{gathered}
F_{0}=\frac{P_{0}}{\vartheta_{0}} \cdot \frac{1}{4 \lambda \cdot \sqrt[3]{V}} \cdot \frac{0,82 A_{0}^{3}}{3 \mu_{0}^{2}} ; \\
B i_{0}=\frac{K_{0}}{\lambda_{0}} \cdot \frac{1}{2} \cdot \sqrt[3]{V},
\end{gathered}
$$

where $P_{O}-$ total power of heat sources, $W ; \vartheta_{\mathrm{o}}-$ maximum permissible overheating of device, degrees; $\lambda_{\mathrm{o}}$ - effective heat conductivity in absence of heat sinks with gas filler, $\mathrm{W} / \mathrm{m} \cdot \mathrm{deg}$; $\mathrm{V}_{0}$ - volume of heated zone, $\mathrm{m}^{3} ; \mathrm{A}_{o}, \mu_{o}$ - amplitude and eigenvalues of characteristic equation for $\mathrm{B}_{\mathrm{I}_{o}} ; \mathrm{K}_{o}$ - average surface heat transfer coefficient $\mathrm{W} / \mathrm{m}^{2} \cdot \mathrm{deg}$.

The initial parameter $F_{o}$ characterizes the thermal regime of following REE design:

- heated zone is in form of a cube $\left(\xi_{X_{\mathrm{O}}}=\xi_{\mathrm{Y}_{\mathrm{O}}}=\xi_{\mathrm{Z}_{\mathrm{O}}}=1\right)$, where

$$
\xi_{\mathrm{I}_{\mathrm{o}}}=21_{\mathrm{mii}} / 21_{\mathrm{i}}, \mathrm{i}=\mathrm{X}, \mathrm{Y}, \mathrm{Z}
$$

- there is no anisotropy in thermal conductivity in volume and heat transfer on surfaces $\left(\lambda_{\mathrm{X}}=\lambda_{\mathrm{Y}}=\lambda_{\mathrm{Z}}=\lambda_{o} ; \mathrm{K}_{\mathrm{X}}=\mathrm{K}_{\mathrm{Y}}=\mathrm{K}_{\mathrm{Z}}=\mathrm{K}_{o}\right)$;

- conductive heat sinks are absent $\left(\lambda_{\max }=\lambda_{\mathrm{O}}\right)$;

- power of heat sources is evenly distributed.

In Fig. 1 shows dependence of parameter

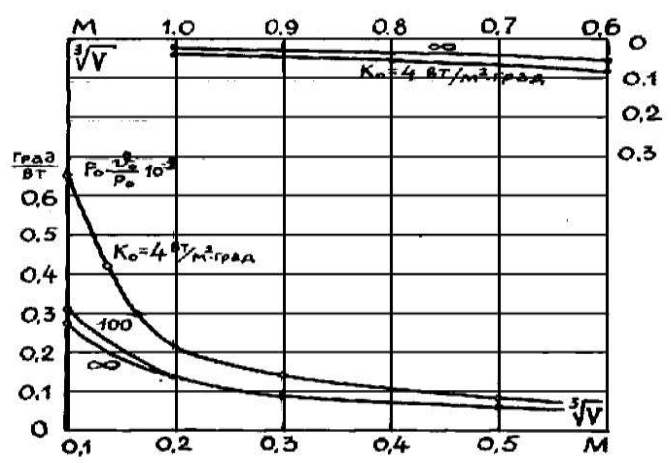

Figure 1. Dependence of initial parameter $F_{O}$ on dimensions of heated zone and intensity of surface heat exchange $K_{0}$ at

$$
\lambda_{o}=0,2 \mathrm{~W} / \mathrm{m} \cdot \mathrm{deg} \text {. }
$$


$F_{o} \cdot \vartheta_{o} / \mathrm{P}_{o} \cdot 10^{2}$ from volume of device heated zone and heat transfer coefficient $\mathrm{K}_{\mathrm{O}}$ characterizing the surface cooling system for devices with effective thermal conductivity $\lambda_{o}=0,2 \mathrm{~W} / \mathrm{m} \cdot \mathrm{deg}[1]$. From graphs it follows that initial parameter $\mathrm{F}_{\mathrm{O}}$ allows minimizing by reducing the ratio $P_{0} / \vartheta_{0}$, increase in volume of heated zone $\mathrm{V}$ and the intensity of surface heat transfer $\mathrm{K}_{\mathrm{O}}$.

Consider each factor individually. The decrease in ratio $\mathrm{P}_{0} / \vartheta_{0}$ causes certain requirements for development of an electric circuit of apparatus.

For implementation of circuit solutions, it is advisable to choose an element base with lowest power consumption and materials with high temperature resistance. If it is necessary to use individual elements with a low permissible superheat temperature $\vartheta_{0}$, it is advisable to separate these elements into an independent group so as not to complicate the provision of a given thermal regime of device design as a whole. This remark is very important to take into account when choosing the elemental base of electric circuit, since after setting the electric circuit designer, it is not possible to influence the dissipated power factor and temperature resistance of circuit elements.

An analysis of dependences (Fig. 1) shows that for singleblock cubic structures of apparatus with a size of $\sqrt[3]{\mathrm{V}} \geq 0,5 \mathrm{~m}$, minimizing the initial parameter Fo due to an increase in volume of heated zone (density of elements) and transition to a more intense surface cooling $\mathrm{K}_{0}=\infty$ system becomes almost impossible.

Conversely, for structures of size $\sqrt[3]{V} \leq 0,5 \mathrm{~m}$, an increase in volume and growth $\mathrm{K}_{\mathrm{O}}$ leads to a three-fold decrease $\mathrm{F}_{\mathrm{O}}$ at $\sqrt[3]{\mathrm{V}}=0,1 \mathrm{~m}$ and by $50 \%$ at $\sqrt[3]{\mathrm{V}}=0,3 \mathrm{~m}$ due to a change $\mathrm{K}_{\mathrm{O}}$ from $4 \mathrm{~W} / \mathrm{m}^{2} \cdot \mathrm{deg}$ to $\infty$. Practically already at $\mathrm{K}_{\mathrm{o}} \geq 100 \mathrm{~W} /$ $\mathrm{m}^{2} \cdot \operatorname{deg}$, limiting case occurs, that is, for devices with gas filling (with low effective thermal conductivity $\lambda_{\mathrm{o}}=0,2 \mathrm{~W} /$

$$
\mathrm{K}_{o}=\frac{K^{1} S_{k} / S}{1+K^{1} S_{k} / \alpha S}
$$

where $\mathrm{K}_{\mathrm{O}}$ - heat transfer coefficient through gas gap from heated zone to casing, $\mathrm{W} / \mathrm{m}^{2} \cdot \mathrm{deg}$;

$\alpha$ - heat transfer coefficient between surface of casing and environment, $\mathrm{W} / \mathrm{m}^{2} \cdot \mathrm{deg}$;

$s_{\mathrm{K}}, s$-surface area of casing and the heated zone, $\mathrm{m}^{2}$.

An analysis of expression (4) and values of heat transfer coefficients for various types of cooling systems [3,5] allows us to outline two ways of increasing $K_{0}$ to minimize parameter $F_{o}$ and synthesize structure with a given thermal regime for maximum overheating. The first way is purely constructive at low values $\mathrm{K}_{\mathrm{o}}$, i.e., for electronic devices designed to function in conditions of natural cooling by air

Calculations of a large number of instrument designs $[2,7]$ showed that there is equality of conductivities between heated zone and the casing, as well as with environment:

$$
\mathrm{K}^{1} \cdot \mathrm{S} \approx \alpha \cdot \mathrm{S}_{\mathrm{K}}
$$

After substituting (5) in (4) we obtain, $\mathrm{K}_{o}=\alpha \cdot S_{\mathrm{K}}$ i.e. use of a casing almost 2 times reduces the efficiency of surface cooling.

When combining casing of apparatus with heated zone, $\left(S_{\mathrm{K}}=S\right), \mathrm{K}^{1} \rightarrow \infty$ and $\mathrm{Ko}=\mathrm{K}$.

Thus, in a purely constructive way, combining instrument cover with heated zone, $\mathrm{K}_{\mathrm{O}}$ it can be doubled (Fig. 2) In this case, it is necessary to ensure good thermal contact between heated zone and casing, for example, using high-conductive pastes in joints between boards (chassis), casing faces, etc. The considered method is most effective when it is necessary

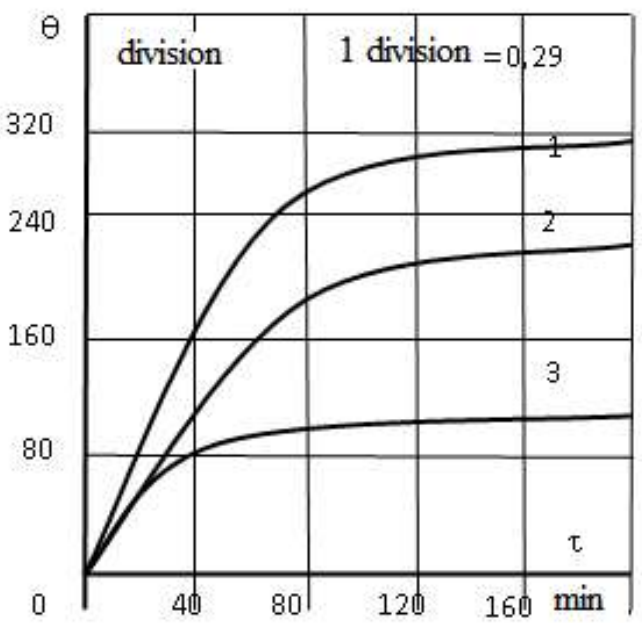

Figure 2. Temperature at the center point heated zone. 1 - in absence of heat sinks; 2 - in presence of heat sinks; 3 - at conclusion of heat sinks to casing.

$\mathrm{m} \cdot \mathrm{deg}$ ), it is inexpedient to use liquid and other more efficient surface cooling systems $[2,6]$.

Extreme minimization $\mathrm{F}_{\mathrm{O}}$ can be achieved through use of forced convective air cooling $(\alpha=10-100 \mathrm{~W} / \mathrm{m} \cdot \mathrm{deg})[3,4]$.

Heat transfer coefficient to maintain tightness (dustproof) equipment.

You can go in another constructive way: to reduce influence of casing on intensity of heat sinks due to violation of tightness and ensuring direct contact of heated zone with 
cooling air through perforation (blinds) openings. Then expression for $\mathrm{K}_{\mathrm{O}}$ in first approximation takes form

$$
K_{0}=K^{\bullet}{ }_{0}\left(1+S_{n e p} / S_{k)},\right.
$$

where $S_{n e p .}$ - area of perforations, $\mathrm{m}^{2} ; \mathrm{K}_{0}-$ is determined by expression (6) at $S_{\text {nep. }}=0$. The ratio $S_{\text {nep. }} / S_{\mathrm{K}}$ is called perforation coefficient. A more rigorous account of perforation is given in [3]. Almost already at $S_{\text {nep. }} / S_{\mathrm{K}}=0.5-0.6$, value $\mathrm{K}_{0}$ is close to $\mathrm{K}_{o}^{*}$ that is, limiting effect of minimization $F_{o}$ is achieved.

The considered constructive methods do not allow significant changes in heat transfer coefficient. For a significant change in intensity of heat transfer on surface of heated zone, a transition from natural to forced surface cooling by blowing air is necessary, that is, additional changes in design of apparatus are required.

In this case, according to equality (2), it is necessary either to simultaneously increase the heat transfer intensity between heated zone and casing $\left(\mathrm{K}^{1}\right)$, casing and environment $(\alpha)$, or first to combine casing with heated zone $\left(\mathrm{K}^{1} \rightarrow \infty\right)$. Otherwise, the growth Ko will be insignificant, despite a significant increase $\alpha$. Thus, in second way of minimizing due to increase $\mathrm{K}_{\mathrm{O}}$, transition to a new cooling system is foreseen with preliminary combining of casing with heated zone, especially in tight-fitting constructions.

An increase in volume of heated zone due to a decrease in density of elements is in conflict with requirement to minimize size of structure, therefore it can only be applied when there are no strict restrictions on size of structure in technical task.

In practice, a change in volume by a factor of 8 (in area $\sqrt[3]{\mathrm{V}}<0.5 \mathrm{~m}$ ) leads $\mathrm{F}_{0}$ to a three-fold decrease at $\mathrm{K}_{0}=4 \mathrm{~W} /$ $\mathrm{m} \cdot \operatorname{deg}$ and a half-time decrease $\mathrm{K}_{0}=\infty$ (Fig. 2). Such a change in volume can be accomplished by switching from high density $\left(\eta_{\mathrm{M}} \geq 1\right)$ mounting to low mounting $\left(\eta_{M} \approx 1\right)$.

\section{CONCLUSIONS}

1. It is established that transition to construction in form of a square "bar" provides most effective minimization of shape parameter. The degree of minimization increases with increasing efficiency of apparatus cooling system

2. Effective minimization of initial parameter can be carried out for apparatus designs with a linear size of less than $0.5 \mathrm{~m}$, due to transition to a low density or to increase the efficiency of surface cooling system. For structures with a linear size of more than $0.5 \mathrm{~m}$, minimizing initial parameter is almost impossible.

\section{REFERENCES}

[1] Н. А. Ярышев, "Расчёт температуры однородного объекта при конвективном теплообмене", Изв. вузов. Приборостроение, 2000 , T.43, № 4, C. 61.

[2] В. И. Шелест, А. С. Кондрашов, "Концептуальный алгоритм теплофизического проектирования радиоэлектронных средств", Технология и конструирование в электронной аппаратуре, 2003, № 5, С. $26-27$.

[3] И. С. Кондрашов, "Моделирование тепловых режимов активных компонентов электронных модулей", Технология и конструирование в электронной аппаратуре, 2006, № 2, С. 43 - 44.

[4] Т. А. Исмаилов, Ш. А. Юсуфов, “Температурное поле электронной платы внутри герметичного радиоэлектронного блока кассетной конструкции", Изв. Вузов. Приборостроение, 2004, Т. 47, № 7, С. 21 -25 .

[5] В. В. Семенец, А. М. Синотин, Т. А. Колесникова та ін. "Исследование зависимости максимального перегрева радиоэлектронного аппарата от его параметров", Системи обробки інформації, 2018, №4, С. 29-34.

[6] Т. А. Колесникова, В. В. Семенец, А. М. Синотин, "Исследование температурных полей РЭА методом регулярного теплового режима", II Міжн. нук.-техн. конф. «Виробництво \& Мехатронні системи» (M\&MS-2018), Харків, 2018, С. 63-65.

[7] В. В. Семенець, А. М. Сінотін, Т. А. Колесникова, "Проектування одноблокових радіоелектронних приладів із заданим тепловим режимом" : Монографія, Харків: ХНУРЕ, 2006, 172 с. 